\title{
Systemic Treatment of Subclinical Mastitis in Lactating Cows with Penethamate Hydriodide
}

\author{
O. Salat, ${ }^{*}$ F. Sérieys,† B. Poutrel,ł L. Durel,§ and L. Goby\# ${ }^{1}$ \\ *2 Avenue du Lioran, 15100 Saint-Flour, France \\ †Filière Blanche, 12 Quai Duguay Trouin, 35000 Rennes, France \\ łInstitut National de la Recherche Agronomique, Unité IASP, 37380 Nouzilly, France \\ $\S$ Le Clos Leveque, 50570 Marigny, France \\ \#Boehringer Ingelheim Animal Health $\mathrm{GmbH}$, Ingelheim, Germany
}

\begin{abstract}
A randomized controlled field trial was performed to evaluate the efficacy of a 3-d treatment regimen with i.m. penethamate hydriodide compared with no treatment in lactating cows with subclinical mastitis. To be included, a cow had to have 2 somatic cell counts (SCC) $>300,000$ cells $/ \mathrm{mL}$ at the last 3 monthly controls, 1 or more quarters with SCC $>250,000$ cells $/ \mathrm{mL}$, and the same bacterial species isolated in 2 consecutive samples 2 to $4 \mathrm{~d}$ apart. A total of 151 quarters from 92 cows were monitored for 2 mo following treatment. Quarter milk samples were examined for bacteriological cure (BC) and SCC at 14, 28, and $60 \mathrm{~d}$ after treatment. Bacteriological cure was defined as not having the same bacterial species isolated from the quarter milk samples taken at 14 and $28 \mathrm{~d}$ posttreatment as in the samples taken before treatment. Systemic treatment with penethamate resulted in $\mathrm{BC}$ in $59.5 \%$ of quarters and $52.2 \%$ of cows, compared with 16.7 and $10.9 \%$ in the untreated cows. Somatic cell count decreased significantly in the penethamate-treated cows, steadily in the case of $\mathrm{BC}$ and transiently when the infections persisted. This study confirms that systemic treatment of subclinical mastitis with penethamate is effective and that $\mathrm{BC}$ of infected quarters has a sustained positive effect on milk SCC during the 2 mo following treatment.
\end{abstract}

Key words: antibiotic, systemic treatment, somatic cell count, subclinical mastitis

\section{INTRODUCTION}

Treatment of subclinical mastitis during lactation has long been considered devoid of interest from an economical standpoint, apart from "blitz" therapy to eliminate infections due to Streptococcus agalactiae

Received March 7, 2007.

Accepted November 3, 2007.

${ }^{1}$ Corresponding author: laurent.goby@boehringer-ingelheim.com
(Craven, 1987). Changes in European Union regulations imposing increasingly stringent standards on bulk milk SCC have proved to be one of the major concerns related to milk quality for dairy producers. Given the continuous restructuring of many herds to increase milk production capacity without a corresponding change in resources (human resources in particular), management practices to prevent IMI are not always carried out sufficiently. Although not always economically profitable, treatment of subclinical mastitis during lactation might, in some cases, effectively complement preventive measures (Swinkels et al., 2005a,b).

These considerations, coupled with particularly rigid European Union health standards, explain why the demand for treating cows with subclinical mastitis, and thus elevated SCC, remains pressing, especially when milk quality is a significant component of price (Hillerton and Berry, 2003). As in many regions of the United States, most European countries operate under a milk marketing system, which provides bonus incentive payments for low bulk milk SCC (and other parameters of milk quality). The use of effective therapy of subclinical IMI is therefore essential if it may increase the $\mathrm{BC}$ and decrease SCC, helping the herd to achieve an SCC bonus payment threshold.

Most of the published studies focusing on treatment of subclinical mastitis during lactation emphasize the use of intramammary treatment (Sol et al., 1997; Gillespie et al., 2002; Oliver et al., 2004; Deluyker et al., 2005). In comparison, specific data on systemic treatment of subclinical mastitis are rather scarce (McDougall, 1998; St. Rose et al., 2003; Beggs and Wraight, 2006; Sandgren et al., 2007). Furthermore, the design of previous studies did not always allow a correct assessment of the bacteriological cure (BC) rate, including prognostic factors, and of the impact of treatment on SCC. Such a study should ideally involve an untreated control group. In a meta-analysis, Sol et al. (1997) evaluated a number of trials involving lactation therapy of subclinical mastitis. This analysis was, however, restricted 
Table 1. General overview of included cows and quarters in penethamate-treated (PEN) and control (CON) cows

\begin{tabular}{|c|c|c|c|c|c|}
\hline \multirow[b]{2}{*}{ Item } & \multicolumn{2}{|c|}{ PEN } & \multicolumn{3}{|c|}{$\mathrm{CON}$} \\
\hline & $\mathrm{n}$ & $\%$ & & $\mathrm{n}$ & $\%$ \\
\hline Cows (quarters) presented & $81(173)$ & & 80 & $(141)$ & \\
\hline $\begin{array}{l}\text { No quarter infection or undetermined } \\
\text { infection status before treatment }\end{array}$ & & & & & \\
\hline results at d 14 or d 28 or both & 5 & 6.2 & 2 & & 2.5 \\
\hline Deviation from planned treatment or & & & & & \\
\hline $\begin{array}{l}\text { additional treatment during the study } \\
\text { Number of cows (quarters) eligible for ana }\end{array}$ & 1 & 1.2 & 0 & & 0 \\
\hline \multicolumn{6}{|c|}{ Number of cows (quarters) eligible for analysis } \\
\hline Bacteriological cure & $46(79)$ & 56.8 & 46 & (72) & 57.5 \\
\hline Bacteriological cure and SCC variations & $38(61)$ & 46.9 & 34 & $(55)$ & 42.5 \\
\hline \multicolumn{6}{|l|}{ Parity } \\
\hline 1 & 21 & 45.6 & 11 & & 23.9 \\
\hline 2 & 16 & 34.8 & 20 & & 43.5 \\
\hline 3 & 9 & 19.6 & 15 & & 32.6 \\
\hline \multicolumn{6}{|l|}{ DIM } \\
\hline$\leq 180 \mathrm{~d}$ & 13 & 28.3 & 16 & & 34.8 \\
\hline$>180 \mathrm{~d}$ & 30 & 65.2 & 22 & & 47.8 \\
\hline Not available & 3 & 6.5 & 8 & & 17.4 \\
\hline \multicolumn{6}{|l|}{ Location of the infected quarter } \\
\hline Right front & 12 & 15.2 & 10 & & 13.9 \\
\hline Left front & 18 & 22.8 & 14 & & 19.4 \\
\hline Right rear & 28 & 35.4 & 20 & & 27.8 \\
\hline Left rear & 21 & 26.6 & 28 & & 38.9 \\
\hline \multicolumn{6}{|l|}{ Number of infected quarters per cow } \\
\hline 1 & 22 & 47.8 & 26 & & 56.5 \\
\hline 2 & 17 & 37.0 & 15 & & 32.6 \\
\hline 3 & 5 & 10.9 & 4 & & 8.7 \\
\hline 4 & 2 & 4.3 & 1 & & 2.2 \\
\hline \multicolumn{6}{|l|}{ Number of pathogens per cow } \\
\hline 1 & 37 & 80.4 & 42 & & 91.3 \\
\hline 2 & 9 & 19.6 & 4 & & 8.7 \\
\hline
\end{tabular}

to cases due to Staphylococcus aureus and did not differentiate the results obtained with the different treatment regimens, routes of administration, or drugs used.

Choosing the systemic route seems attractive when one considers the often-chronic nature of subclinical infections with the deep-rooted location of infected sites and frequent simultaneous involvement of several quarters (Barkema et al., 1997). The antiinfective candidate must show high affinity for the mammary gland and bactericidal effects against gram-positive organisms. Penethamate hydriodide is an ester of penicillin $\mathrm{G}$ that easily crosses the blood-milk barrier and concentrates in udder tissues and milk after i.m. administration (Ziv, 1980). Penethamate is licensed in many countries for the treatment of subclinical mastitis due to major gram-positive pathogens. It is active against streptococci and penicillin-sensitive Staph. aureus in milk (Louhi et al., 1992) and within mammary epithelial cells (Madgwick et al., 1989; Almeida et al., 2007).

The primary objective of this study was to evaluate the efficacy of a systemic treatment with penethamate hydriodide in lactating cows with recently acquired subclinical mastitis compared with a negative control group. A second objective was to assess the short- and long-term effects of penethamate treatment on subsequent SCC of those cows.

\section{MATERIALS AND METHODS}

\section{Herds and Cows Selected}

Selection of Farms. The study was carried out by 8 veterinarian investigators on 53 farms located in different regions of France. Farms with an expected high prevalence of contagious pathogens (for example, Staph. aureus or Streptococcus uberis) were targeted. To be included, a farm had to 1) be a participant of the French DHIA (France Contrôle Laitier, Paris, France); and 2) have more than $15 \%$ of cows with a monthly milk SCC $>300,000$ cells $/ \mathrm{mL}$ over the past $3 \mathrm{mo}$ and an average incidence of severe clinical mastitis cases (with systemic signs) of less than $15 \%$ per yr. This information could be obtained from the DHIA and on-farm records, respectively.

Median bulk milk SCC in the month before inclusion in the study was 277,000 cells $/ \mathrm{mL}$. Herd size ranged from 20 to 140 lactating cows. The cow breeds were French Holstein (78.9\%), Montbeliarde (10.5\%), or 
crossbreed (10.6\%). The majority were housed in cubicles, with straw bedding judged sufficient or inadequate in 68.3 and $14.9 \%$, respectively. This information was missing for the remaining farms. All were milked twice daily.

Inclusion of Cows. To be included in the study, the cows had to meet the following criteria: 1) 2 out of the 3 most recent monthly cow milk SCC $>300,000$ cells/ $\mathrm{mL}$; 2) no concurrent disease requiring treatment; 3) no teat lesions; 4) no clinical mastitis; 5) no systemic or intramammary antiinfectious or antiinflammatory treatments (e.g., antibiotics, nonsteroidal antiinflammatory drugs, corticosteroids) during the preceding 2 wk; and 6) no chronic subclinical mastitis during the previous or current lactation (i.e., 3 consecutive monthly milk SCC $>300,000$ cells $/ \mathrm{mL}$ ). Only quarters with an inflammatory reaction ( $\mathrm{SCC}>250,000$ cell $\mathrm{s} / \mathrm{mL}$ ) and with the same bacterial species cultured in 2 pretreatment samples were included in the follow-up. Cows with mixed infections in the same udder quarter were not included, but cows with several quarters infected with different pathogens were included.

\section{Treatment}

Cows meeting the inclusion criteria were given a case number in chronological order and then allocated to treatment or nontreatment using a printed label (penethamate or control) enclosed in case-numbered printed envelopes and following a preestablished randomization list. Treatment consisted of daily i.m. injections of penethamate hydriodide (Mamyzin/Stop M-, Boehringer Ingelheim $\mathrm{GmbH}$, Ingelheim, Germany) for 3 consecutive days at a dose of $10 \mathrm{~g} /$ animal on $\mathrm{d} 1$, followed by $5 \mathrm{~g}$ /animal on $\mathrm{d} 2$ and $\mathrm{d} 3$ ( $1 \mu \mathrm{g}$ of penethamate hydriodide provides 1 IU of penicillin G), in accordance with the approved commercial product label for France. The first injection was administered by the investigator and subsequent injections by the farmer.

\section{Milk Sampling and Laboratory Procedures}

Before treatment, milk samples from each quarter of the included cows were collected twice for bacteriological examination (aseptic sampling): 2 to $4 \mathrm{~d}$ before treatment $(d-n)$ and immediately before treatment $(d 0)$. Additional milk samples were also taken on d 0 from each quarter into flasks containing $0.1 \%$ potassium dichromate for SCC determination. Milk samples were taken on d 14, 28, and 60 after treatment for bacterial examination and SCC determination.

Bacteriological culture and identification were carried out according to National Mastitis Council standards (Harmon et al., 1990). Quarter milk SCC was determined using a Fossomatic 5000 device (Foss Electric, Hillerd, Denmark) according to International Dairy Federation standards (IDF, 1995). Measurement was carried out within $2 \mathrm{~d}$ of collection.

\section{Definitions of $B C$}

Bacteriological cure of the quarter was defined as a negative culture at d 14 and 28 or the presence of a bacterial species different from the one isolated in the samples collected before treatment. All quarters with a missing or contaminated sample taken on d 14 or 28 were excluded from the analysis.

In addition, the $\mathrm{BC}$ status of the cows was divided into 3 groups: 1) totally cured if all included quarters were cured; 2) partly cured if only some quarters were cured; and 3) not cured if no quarter was cured.

\section{Statistical Analysis}

The predefined statistical unit was the cow. Categorical variables such as parity ( 1 or $>1$ ), stage of lactation (DIM $>180 \mathrm{~d}$ or $\leq 180 \mathrm{~d}$ ), and number of infected quarters per cow before treatment (1, 2, 3, or 4) were compared between the groups at baseline using $\chi^{2}$ tests. Bacteriological cure rates were compared between the 2 treatment groups using logistic regression. To explore the robustness of the results of this analysis, a series of sensitivity analyses was performed with prognostic factors added to the logistic regression model (thus adjusting the treatment effects for these prognostic factors). The SCC data were analyzed on the natural log (ln) scale, based on the mean of the included quarters per cow. The treatments were primarily compared with respect to SCC using a repeated-measures analysis of covariance (ANCOVA) model, with fixed effects for time and treatment and baseline SCC as covariate. The repeated-measures analysis was performed without assuming any specific covariance structure for the repeated measurements within the subjects. Again, a series of sensitivity analyses was performed with prognostic factors added to the model; the prognostic factors considered were the same as for the logistic regression analysis of $\mathrm{BC}$ rates.

In addition, SCC were compared between groups separately for each timepoint using Student's $t$-test, and paired sample $t$-tests were used for within-group comparisons to the initial value. The statistical analyses were carried out using SAS software (release 8.02, SAS Institute Inc., Cary, NC). Statistical significance was defined as $P<0.05$. 
Table 2. Bacteriological cure rate of quarters according to pathogen isolated at $\mathrm{d} 0$ in penethamate-treated (PEN) and control (CON) cows

\begin{tabular}{lccccc}
\hline & \multicolumn{2}{c}{ PEN } & & \multicolumn{2}{c}{ CON } \\
\cline { 2 - 3 } \cline { 6 - 7 } Pathogen & $\mathrm{n}$ & $\%$ & & $\mathrm{n}$ & $\%$ \\
\hline Staphylococcus aureus & $6 / 19$ & 31.6 & & $2 / 30$ & 6.7 \\
CNS & $17 / 27$ & 63 & & $3 / 18$ & 16.7 \\
Streptococcus uberis & $9 / 16$ & 56.2 & & $4 / 13$ & 30.8 \\
Streptococci except Strep. uberis & $12 / 14$ & 85.7 & & $3 / 8$ & 37.5 \\
Total streptococci & $21 / 30$ & 70 & & $7 / 21$ & 33.3 \\
Corynebacterium bovis & $3 / 3$ & 100 & & $0 / 3$ & 0 \\
All pathogens & $47 / 79$ & 59.5 & & $12 / 72$ & 16.7 \\
\hline
\end{tabular}

${ }^{1}$ Excluding enterococci.

\section{RESULTS}

\section{Cows and Quarters Eligible for Analysis}

In total, 100 lactating cows (168 quarters) were included in the trial. The bacteriological status at $\mathrm{d} 14$ and 28 could be determined on 151 quarters from 92 cows: 46 (79 quarters) in the penethamate-treated group and 46 (72 quarters) in the control group (Table 1). Of these, 3 consecutive SCC at d 14, 28 , and 60 were available for 72 cows (116 quarters). Seven cows were excluded because the bacterial result was missing at $d$ 14 or 28 , and 1 cow was excluded because she needed additional therapy soon after inclusion.

There was no statistical difference for average parity and stage of lactation between the treatment and control groups ( $P=0.08$ and $P=0.15$, respectively). However, there were more cows in first lactation in the penethamate group. The number and location of the infected quarters were equally distributed in both groups, with infections predominant in the rear quarters $(65 \%)$. In almost half the cows, 2 or more quarters were affected (Table 1). On average, 1.7 quarters per cow had a positive culture (range: 1 to 4 ). Most cows were infected by only 1 pathogen species, and only rarely by 2 pathogens. The overall distribution of the different pathogens was comparable between groups except for Staph. aureus, for which the unbalanced distribution required specific adjustment in the analysis.

\section{Bacteriological Cure}

Systemic treatment with penethamate resulted in a bacteriological quarter cure rate of $59.5 \%$ compared with a spontaneous BC rate of $16.7 \%$ in the untreated control quarters. Cure rates for Staph. aureus, CNS, and overall streptococcal IMI were better in the penethamate treatment group compared with spontaneous cure (Table 2).

Considering that a cow is totally cured if all its infected quarters are bacteriologically cured, the overall $\mathrm{BC}$ rate was $52.2 \%$ in the penethamate-treated cows vs. $10.9 \%$ in the untreated cows $(P<0.001$; Table 3$)$. In the penethamate group, $21.7 \%$ of cows had no quarters cured compared with $76.1 \%$ in the control group, and $78.3 \%$ of cows had at least one quarter cured compared with $23.9 \%$ in the control group $(P<0.0001$; Table 3$)$. The chance of BC was significantly influenced by the number of infected quarters (Table 4). Cure rates after penethamate treatment were larger than spontaneous cure rates regardless of the number of affected quarters per cow. The proportion of totally cured cows showed a significant decrease as the number of affected quarters increased: in the penethamate-treated group, $72.7 \%$ of cows with only one quarter infected at d 0 were completely cured, whereas cows with 3 or 4 quarters infected were unlikely to be cured (cure rates of 14.3 and 0 , respectively). In contrast, the $\mathrm{BC}$ rate was not significantly modified by the presence of Staph. aureus, parity, the involvement of rear quarters, or the stage of lactation (Table 4). The significant treatment effect observed in the study was not relevantly changed when the statistical analysis was adjusted for imbalances with respect to prognostic factors at baseline, indicating that those imbalances did not have a relevant influence on the study outcomes. Logistic regression analyses also did not show any evidence for an interaction between treatment and any prognostic factors.

Only 7 cases of clinical mastitis were observed during the course of the study ( 2 in the penethamate group and 5 in the control group), with only 3 cases identified within the first $28 \mathrm{~d}$ of follow-up ( 1 in the penethamate

Table 3. Bacteriological cure rate in penethamate-treated (PEN) and control (CON) cows

\begin{tabular}{|c|c|c|c|c|c|c|c|c|}
\hline & \multicolumn{2}{|c|}{ PEN } & \multicolumn{2}{|c|}{$\mathrm{CON}$} & \multirow[b]{2}{*}{$\mathrm{OR}^{1}$} & \multicolumn{2}{|c|}{$\begin{array}{c}95 \% \text { confidence } \\
\text { interval }\end{array}$} & \multirow[b]{2}{*}{$P$-value } \\
\hline & $\mathrm{n}$ & $\%$ & $\mathrm{n}$ & $\%$ & & Low & High & \\
\hline Number of cows & 46 & & 46 & & & & & \\
\hline Cows with all quarters cured & 24 & 52.2 & 5 & 10.9 & 9.775 & 2.953 & 32.352 & 0.0002 \\
\hline Cows not cured & 22 & 47.8 & 41 & 89.1 & - & - & - & \\
\hline Cows with no quarter cured & 10 & 21.7 & 35 & 76.1 & & & & \\
\hline Cow with some quarters cured & 12 & 26.1 & 6 & 13.0 & & & & \\
\hline Cow with at least 1 quarter cured & 36 & 78.3 & 11 & 23.9 & 12.249 & 4.269 & 35.151 & $<0.0001$ \\
\hline
\end{tabular}

${ }^{1}$ Odds ratio (unadjusted estimates). 
Table 4. Bacteriological cure (BC) of cows after adjustment for different prognostic factors in penethamate-treated (PEN) and control (CON) animals

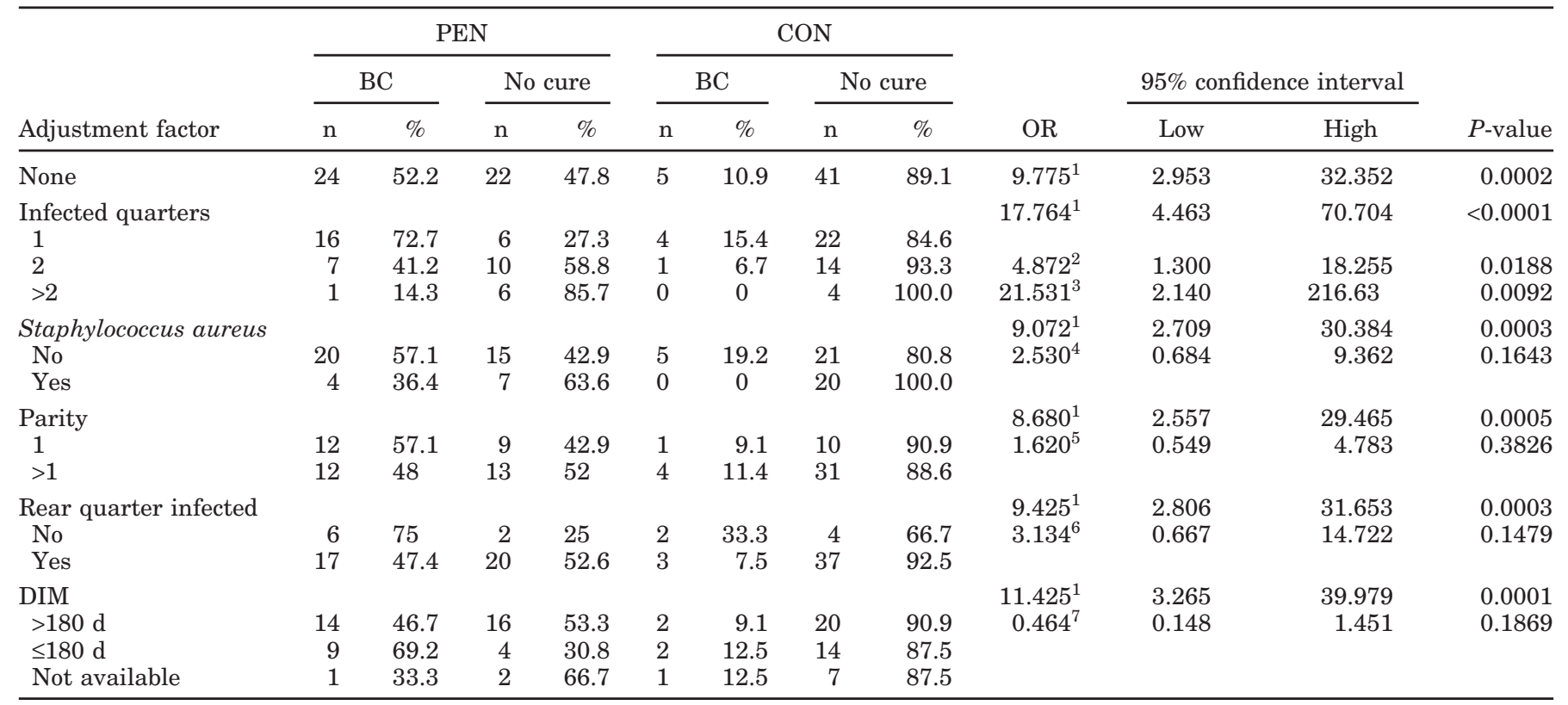

${ }^{1}$ Odds ratio (OR) estimate for PEN vs. CON.

${ }^{2} \mathrm{OR}$ estimate for 1 vs. 2 quarters.

${ }^{3} \mathrm{OR}$ estimate for 1 vs. $>2$ quarters.

${ }^{4} \mathrm{OR}$ estimate for absence vs. presence of Staph. aureus

${ }^{5} \mathrm{OR}$ estimate for parity 1 vs. parity $>1$.

${ }^{6} \mathrm{OR}$ estimate for absence vs. presence of rear quarter infection.

${ }^{7}$ OR estimate for DIM $>180 \mathrm{~d}$ vs. $\leq 180 \mathrm{~d}$.

group and 2 in the control group). In all cases, the responsible organism was identical to that isolated on d 0. Streptococcus uberis was involved in 3 cases, CNS in 2 cases, and Staph. aureus and Corynebacterium bovis in the remaining 2 cases.

\section{SCC}

The variations of cow SCC between d 14 and 60 were strongly influenced by baseline values at $\mathrm{d} 0$ and by treatment $(P<0.001)$. According to the repeated-measures ANCOVA, the baseline-adjusted log-transformed SCC values were reduced by $0.827 \mathrm{ln}$ units for penethamate compared with the control $(P<0.001)$, which corresponds to a reduction factor of about $44 \%$ on the original measurement scale. Stage of lactation (DIM) was the only prognostic factor that reached statistical significance at the $0.05 \%$ level, in favor of cows in the earlier stage of lactation.

The mean cow SCC before treatment did not differ between the 2 groups (Table 5). In cows treated with penethamate, mean SCC was lower at d 14, 28, and 60 than at $d 0$, and lower than in the control cows (Table $5)$. In the control group, SCC at d 14, 28, and 60 was not significantly different from the value at $d 0$. Split results according to the cure status of individual cows showed that BC, with or without treatment, resulted in an overall significant decrease of SCC (Table 6). Somatic cell counts remained high when the infection persisted, even though a transient decrease was observed at d 28 in the penethamate-treated cows (Table 6).

\section{DISCUSSION}

The inclusion criteria in this trial selected cows with a natural recent subclinical infection. Conversely, cows with chronic infection and a history of increased SCC during the preceding or current lactation were excluded. Moreover, only animals with of parity 3 or less were included. Selected cows therefore had a greater probability of cure (Deluyker et al., 1999, 2005). They were likely to respond positively to antibiotic treatment during lactation, which could, therefore, be economically justified (Swinkels et al., 2005a,b). Other prognostic factors such as number and location of infected quarters or stage of lactation can also have a considerable influence on the healing of infections treated during lactation (Owens et al., 1997; Sol et al., 1997; Deluyker 
Table 5. Variations in SCC of initially infected quarters in penethamate-treated (PEN) and control (CON) animals

\begin{tabular}{|c|c|c|c|c|c|c|c|c|}
\hline \multirow[b]{2}{*}{ Day } & \multirow[b]{2}{*}{ Treatment } & \multirow[b]{2}{*}{$\mathrm{n}^{1}$} & \multicolumn{2}{|c|}{ Ln SCC } & \multicolumn{2}{|c|}{ SCC (numerical) } & \multirow{2}{*}{$\begin{array}{l}\text { Comparison } \\
\text { between } \\
\text { groups }^{3}\end{array}$} & \multirow{2}{*}{$\begin{array}{l}\text { Comparison vs } \\
\text { d } 0 \text { value }^{4}\end{array}$} \\
\hline & & & Mean & SEM & Mean $^{2}$ & Mean \pm SEM & & \\
\hline \multirow[t]{2}{*}{0} & PEN & 38 & 13.784 & 0.160 & 969 & $826 \pm 1,137$ & \multirow[t]{2}{*}{ NS } & - \\
\hline & $\mathrm{CON}$ & 34 & 13.931 & 0.125 & 1,122 & $991 \pm 1,272$ & & - \\
\hline \multirow[t]{2}{*}{14} & PEN & 38 & 13.000 & 0.242 & 442 & $347 \pm 564$ & \multirow[t]{2}{*}{$<0.05$} & 0.001 \\
\hline & $\mathrm{CON}$ & 34 & 13.852 & 0.192 & 1,037 & $856 \pm 1,257$ & & NS \\
\hline \multirow[t]{2}{*}{28} & PEN & 38 & 12.665 & 0.224 & 316 & $253 \pm 396$ & \multirow[t]{2}{*}{$<0.001$} & $<0.001$ \\
\hline & $\mathrm{CON}$ & 34 & 13.925 & 0.181 & 1,116 & $931 \pm 1,337$ & & NS \\
\hline \multirow[t]{2}{*}{60} & PEN & 38 & 12.849 & 0.224 & 380 & $304 \pm 476$ & \multirow[t]{2}{*}{$<0.05$} & $<0.001$ \\
\hline & $\mathrm{CON}$ & 34 & 13.588 & 0.169 & 797 & $673 \pm 943$ & & NS \\
\hline
\end{tabular}

\footnotetext{
${ }^{1}$ Only cows with quarter SCC available at $\mathrm{d} 0,14,28$, and 60 were considered.

${ }^{2}$ Arithmetic mean $(\times 1,000$ cells $/ \mathrm{mL})$.

${ }^{3}$ Student's $t$-test.

${ }^{4}$ Paired samples $t$-test.
}

et al., 2005). None of those factors, however, had a statistically significant effect on BC in this trial. The presence of Staph. aureus, usually associated with lower cure rates (Sol et al., 1997), did not significantly increase the risk of treatment failure.

The overall bacteriological profile of the 2 groups was comparable. Nonagalactiae streptococci, Staph. aureus, and CNS were found to be responsible for more than $90 \%$ of the subclinical infections recorded here. These data are consistent with those reported in most publications focusing on subclinical mastitis, although the relative importance of each bacterium varies according to the survey and country (Sobiraj et al., 1997; McDougall, 1998; Deluyker et al., 2005). In France, Staph. aureus and Strep. uberis are the major pathogens most frequently isolated; Streptococcus agalactiae has almost completely disappeared (Jouy et al., 2003).

The $\mathrm{BC}$ rate of all the bacterial pathogens combined was good at both the quarter and cow levels. In the treated group, $59.5 \%$ of quarters and $52.2 \%$ of cows were cured, which is 3.6 times and 4.8 times greater, respectively, than the $\mathrm{BC}$ rates in the control group. The rate of spontaneous cure was rather low but comparable to that stated in previous publications using a similar definition of BC (St. Rose et al., 2003; Deluyker et al., 2005; Sandgren et al., 2007). Conversely, the number of cases developing into clinical mastitis was lower than that observed in earlier studies and was significantly reduced in the cows receiving systemic treatment with penethamate compared with the nontreated cows (St. Rose et al., 2003; Deluyker et al., 2005). This may be explained by the recent nature of the cases selected in our study protocol. Nevertheless, the lower frequency of progression to clinical mastitis after systemic treatment compared with intramammary treatment has already been reported (Shephard et al., 2000; Sandgren et al., 2007). Deluyker et al. (2005) observed a 3 -fold increase in the number of clinical cases after extended ( $8 \mathrm{~d}$ vs. $2 \mathrm{~d}$ ) intramammary

Table 6. Variations in SCC of initially infected quarters according to cure status in penethamate-treated $(\mathrm{PEN})$ and control $(\mathrm{CON})$ animals

\begin{tabular}{|c|c|c|c|c|c|c|c|c|c|c|c|}
\hline \multirow[b]{3}{*}{ Day } & \multirow[b]{3}{*}{ Treatment } & \multirow[b]{3}{*}{$\mathrm{n}^{1}$} & \multicolumn{4}{|c|}{ Noncured cows } & \multicolumn{5}{|c|}{ Totally or partly cured cows } \\
\hline & & & \multicolumn{2}{|c|}{ Ln SCC } & \multicolumn{2}{|r|}{$\mathrm{SCC}$} & \multirow[b]{2}{*}{$\mathrm{n}^{1}$} & \multicolumn{2}{|c|}{ Ln SCC } & \multicolumn{2}{|r|}{$\mathrm{SCC}$} \\
\hline & & & Mean & SEM & Mean $^{2}$ & Mean \pm SEM & & Mean & SEM & Mean $^{2}$ & Mean $\pm \mathrm{SEM}$ \\
\hline \multirow[t]{2}{*}{0} & PEN & 11 & 13.915 & 0.333 & 1,105 & $792 \pm 1,541$ & 27 & 13.731 & 0.183 & 919 & $765 \pm 1,104$ \\
\hline & $\mathrm{CON}$ & 25 & 13.818 & 0.143 & 1,002 & $869 \pm 1,157$ & 9 & 14.243 & 0.230 & 1,533 & $1,218 \pm 1,93$ \\
\hline \multirow[t]{2}{*}{14} & PEN & 11 & 14.261 & 0.283 & 1,561 & $1,176 \pm 2,072$ & 27 & $12.486^{* *}$ & 0.263 & 265 & $203 \pm 344$ \\
\hline & $\mathrm{CON}$ & 25 & 14.102 & 0.223 & 1,332 & $1,066 \pm 1,664$ & 9 & $13.158^{*}$ & 0.280 & 518 & $392 \pm 686$ \\
\hline \multirow[t]{2}{*}{28} & PEN & 11 & $12.788^{*}$ & 0.416 & 358 & $236 \pm 543$ & 27 & $12.602 * *$ & 0.270 & 297 & $227 \pm 389$ \\
\hline & $\mathrm{CON}$ & 25 & 14.048 & 0.217 & 1,262 & $1,016 \pm 1,568$ & 9 & $13.585^{*}$ & 0.318 & 794 & $578 \pm 1,091$ \\
\hline \multirow[t]{2}{*}{60} & PEN & 11 & 13.473 & 0.413 & 710 & $470 \pm 1,073$ & 27 & $12.595 * *$ & 0.256 & 295 & $228 \pm 381$ \\
\hline & $\mathrm{CON}$ & 25 & 13.751 & 0.178 & 938 & $785 \pm 1,120$ & 9 & $13.135^{*}$ & 0.385 & 506 & $345 \pm 744$ \\
\hline
\end{tabular}

\footnotetext{
${ }^{1}$ Only cows with quarter SCC available at d 0, 14, 28, and 60 were considered.

${ }^{2}$ Arithmetic mean $(\times 1,000$ cells $/ \mathrm{mL})$.

$* P<0.05 ; * * P<0.001$ [comparison vs. d 0 value (paired samples $t$-test)].
} 
treatment, which might be explained by an increased risk of iatrogenic infection (Beggs and Wraight, 2006).

As reported by other researchers (Poutrel, 1978; Sol et al., 1997), the number of infected quarters per cow was negatively correlated with the $\mathrm{BC}$ of cows: when only 1 quarter was infected, the odds of cow cure was about 5 times greater than when 2 quarters were infected and about 20 times greater than when 3 or more quarters were infected. With the treatment protocol used in this study, reasonable cure rates were achieved in cows with no more than 2 quarters infected.

However, treatment success varies according to the bacterial species responsible (Deluyker et al., 2005; Sandgren et al., 2007). The cure rates recorded for streptococcal infections were greater than those published (St. Rose et al., 2003), which may again be explained by the inclusion criteria excluding chronic persistent cases. The BC rate for Strep. uberis was slightly lower than for other streptococci, but not very different from those previously reported (Oliver et al., 2004; Sandgren et al., 2007).

Bacteriological cure of quarters infected by Staph. aureus was less than for other infectious agents, but significantly greater compared with spontaneous healing, in agreement with published results (Sol et al., 1997, Oliver et al., 2004). Not taking into account the animal's own abilities (Sol et al., 1997; Deluyker et al., 2005), $\beta$-lactamase production by Staph. aureus strains has a great effect on BC. It has been clearly established that the $\mathrm{BC}$ rate is much lower, regardless of the antibiotic used, for the $\beta$-lactamase-producing strains compared with the nonproducing strains (Barkema et al., 2006). In this study, because there was no preliminary screening test for penicillin resistance, all Staphylococcus strains were treated with penethamate. Prevalence of penicillin resistance in bovine Staph. aureus varies from country to country (Anderson et al., 2006; Moroni et al., 2006); in France, approximately $45 \%$ of strains isolated from IMI are $\beta$-lactamase-producing (AFSSA, 2006). This characteristic appears to be homogeneous within the herd, because the Staph. aureus strains implicated in subclinical mastitis are either all non- $\beta$ lactamase-producing or all $\beta$-lactamase-producing in approximately $70 \%$ of herds (Sérieys and Giquel-Bruneau, 2005). The prior selection of strains determined by penicillin sensitivity would probably have improved the BC rate (Ziv and Storper, 1985), because the treatment of penicillin-resistant strains during lactation is not advised elsewhere (Barkema et al., 2006).

Approximately two-thirds of CNS infections were cured following treatment. Although these infections trigger smaller increases in SCC than do the major pathogens (Djabri et al., 2002), they potentially persist in the affected quarters for a long time, and spontane- ous cure is rare (Chaffer et al., 1999; Sears and McCarthy, 2003). Some strains are penicillin-resistant (Gentilini et al., 2002; Rajala-Schultz et al., 2004). Apparent treatment failure may also be explained by rapid reinfection by another CNS species (Deluyker et al., 2005).

As has been observed with other drugs, it is likely possible to improve the cure rate of all penicillin-sensitive staphylococci by prolonging treatment with penethamate (Funke, 1982; Ziv and Storper, 1985; Oliver et al., 2004; Deluyker et al., 2005) or by using it in combination with an intramammary treatment (Owens et al., 1988).

In this trial, antibiotic therapy had a very marked and sustained effect on SCC, which is seldom reported (Mc Dougall, 1998; Shephard et al., 2000; Beggs and Wraight, 2006). When considering SCC at the cow level from composite quarter samples whether infected or not, St. Rose et al. (2003) noted a decrease in SCC in cows receiving penethamate, albeit to a lesser extent. Repeated-measures ANCOVA showed that this decrease was largely correlated with $\mathrm{BC}$ and treatment. Analysis of SCC in cows treated but not cured highlighted a statistically significant decrease in SCC at d 28 in the treatment group compared with the control group and baseline values. Although a chance effect cannot be excluded, it may also be assumed that the treatment had some effect on SCC that cannot be reduced to $\mathrm{BC}$ of quarters only. It can be hypothesized that, even if antibiotic treatment does not manage to eliminate the infection completely, it nevertheless reduces, albeit temporarily, the microbial population in the infected quarters (Owens et al., 1999), resulting in a diminished influx of leukocytes into the milk and a consequent reduction in SCC (Rosenberg et al., 2002). As a result, to conclude that an animal is cured solely on the basis of a reduction in SCC 1 mo after treatment probably overestimates the reality of a $\mathrm{BC}$, even if this observation is of major importance to the stockman; all too often, this is the only reason for treating subclinical mastitis during lactation. In contrast, once $\mathrm{BC}$ has been achieved, the reduction in SCC persists and SCC remains significantly lower on d 60 compared with pretreatment values.

The choice of the systemic route for subclinical infections is based on pharmacokinetic and economic criteria. First, provided that the active drug diffuses properly in the mammary gland, it is uniformly distributed in the infected quarter following parenteral administration. Once this occurs, the achieved concentration must remain above the MIC for a sufficient period of time (Ziv, 1980). If these conditions are met, there is an economic interest in treating several quarters simultaneously without increasing the treatment cost, and with no need for prior determination of which quarters are 
subclinically infected. Given that cows with subclinical mastitis are, on average, infected in 2 quarters (Barkema et al., 1997), it is possible to expect collateral effects on nontargeted quarters, as observed in the systemic treatment of clinical mastitis (Sérieys et al., 2005). This interesting outcome might be considered when assessing the economic benefits of lactational antibiotic treatment, given its overall impact on cow milk SCC and bulk tank milk SCC, and therefore on the incentive bonus for the milk producer. According to Swinkels et al. (2005a,b) and based on the BC observed in this trial, a 3-d penethamate treatment of subclinical staphylococcal and environmental streptococcal mastitis would be economically profitable in most cases. For cows with more than 2 infected quarters, however, the expected cure rate is so low that the value of such a treatment is questionable.

\section{CONCLUSIONS}

A 3-d systemic treatment of subclinical mastitis with penethamate resulted in a bacteriological cure rate of more than half the cows affected and brought about a significant reduction in the SCC of these animals. This SCC decrease persisted when there was a bacteriological cure, but was only transient in its absence. The value of systemically administered penethamate lies equally in the fact that the systemic route carries less risk in terms of further mammary infection than the local route, and that it does not require prior identification of the affected quarter or quarters to treat. Our results show that the success of such treatment depends greatly on the number of affected quarters in the cow. As chances of a cure diminish with respect to the number of quarters affected, careful consideration must be given to the decision to treat during lactation when more than 2 quarters are affected. Similarly, when a resistant strain of Staphylococcus aureus is suspected, a prior test for $\beta$-lactamase production is advised to maximize the chances of success for treatment during lactation.

\section{ACKNOWLEDGMENTS}

The authors would like to thank all of the investigators involved in the study, A. Fromageau (INRA, Nouzilly, France) for the bacteriological examinations and the Centre Interprofessionnel Laitier Auvergne Limousin (Theix, France) for the cell counts.

\section{REFERENCES}

AFSSA. 2006. FARM 2003-2004 Rapport du programme français de surveillance de l'antibiorésistance des bactéries d'origine animale (French antimicrobial resistance monitoring in bacteria of animal origin). http://www.afssa.fr/Documents/SANT-Ra-FARM.pdf Accessed Dec. 20, 2007. Agence Française de Sécurité Sanitaire des Aliments (AFSSA), France.

Almeida, R. A., D. Patel, G. M. Friton, and S. P. Oliver. 2007. Intracellular killing of mastitis pathogens by penethamate hydriodide following internalization into mammary epithelial cells. J. Vet. Pharmacol. Therap. 30:151-156.

Anderson, K. L., R. L. Lyman, S. M. Bodeis-Jones, and D. G. White. 2006. Genetic diversity and antimicrobial susceptibility profiles among mastitis causing Staphylococcus aureus isolated from bovine milk samples. Am. J. Vet. Res. 67:1185-1191.

Barkema, H. W., Y. H. Schukken, T. J. G. M. Lam, D. T. Galligan, M. L. Beiboer, and A. Brand. 1997. Estimation of interdependence among quarters of the bovine udder with subclinical mastitis and implications for analysis. J. Dairy Sci. 80:1592-1599.

Barkema, H. W., Y. H. Schukken, and R. N. Zadoks. 2006. Invited review: The role of cow, pathogen, and treatment regimen in the therapeutic success of bovine Staphylococcus aureus mastitis. J. Dairy Sci. 89:1877-1895.

Beggs, D. S., and M. D. Wraight. 2006. Pilot study - Parenteral treatment of recently acquired subclinical mastitis during lactation. Vet. J. 84:50-52.

Chaffer, M., G. Leitner, M. Winkler, A. Glickman, O. Krifucks, E. Ezra, and A. Saran. 1999. Coagulase-negative staphylococci and mammary gland infections in cows. Zentralbl. Veterinamed B. 46:707-712.

Craven, N. 1987. Efficacy and financial value of antibiotic treatment of bovine clinical mastitis during lactation - A review. Br. Vet. J. 143:410-422.

Deluyker, H. A., S. T. Chester, and S. N. Van Oye. 1999. A multilocation clinical trial in lactating dairy cows affected with clinical mastitis to compare efficacy of treatment with intramammary infusions of a lincomycin/neomycin combination with an ampicillin/cloxacillin combination. J. Vet. Pharmacol. Therap. 22:274282.

Deluyker, H. A., S. N. Van Oye, and J. F. Boucher. 2005. Factors affecting cure and somatic cell count after pirlimycin treatment of subclinical mastitis in lactating cows. J. Dairy Sci. 88:604-614.

Djabri, B., N. Bareille, F. Beaudeau, and H. Seegers. 2002. Quarter milk somatic cell count in infected dairy cows: A meta-analysis. Vet. Res. 33:335-357.

Funke, H. 1982. Practical experiences in the treatment of clinical mastitis. Pages 1-13 in Proc. Novo Symposium on Mastitis Control and Therapy. Novo Copenhagen, Copenhagen, Denmark.

Gentilini, E., G. Denamiel, A. Betancor, M. Rebuelto, M. Rodriguez Fermepin, and R. A. De Torrest. 2002. Antimicrobial susceptibility of coagulase-negative staphylococci isolated from bovine mastitis in Argentina. J. Dairy Sci. 85:1913-1917.

Gillespie, B. E., H. Moorehead, P. Lunn, H. H. Dowlen, D. L. Johnson, K. C. Lamar, M. J. Lewis, S. J. Ivey, J. W. Hallberg, S. T. Chester, and S. P. Oliver. 2002. Efficacy of extended pirlimycin hydrochloride therapy for treatment of environmental Streptococcus spp. and Staphylococcus aureus intramammary infections in lactating dairy cows. Vet. Ther. 3:373-380.

Harmon, R. J., R. J. Eberhart, D. E. Jasper, B. E. Langlois, and R. A. Wilson. 1990. Microbial procedures for the diagnosis of bovine udder infection. 3rd ed. National Mastitis Council Inc., Arlington, VA.

Hillerton, J. E., and E. A. Berry. 2003. The management and treatment of environmental streptococcal mastitis. Vet. Clin. North Am. Food Anim. Pract. 19:157-169.

IDF (Int. Dairy Fed.) 1995. Enumeration of somatic cells. FIL-IDF Standard no. 148A. IDF, Brussels, Belgium.

Jouy, E., D. Meunier, M. Chazel, I. Kempf, M. Kobisch, J. P. Orand, and P. Sanders. 2003. RESAPATH: Réseau de surveillance de la résistance aux antibiotiques chez les principales bactéries pathogènes des bovins, des porcs et des volailles. Description des espèces bactériennes et des pathologies enregistrées en 2002. Bulletin Epidémiologique de l'Afssa. 9:5-6.

Louhi, M., K. Inkinen, V. Myllys, and M. Sandholm. 1992. Relevance of sensitivity testings (MIC) of S. aureus to predict the antibacterial action in milk. J. Vet. Med. B. 39:253-262. 
Madgwick, L., S. Mayer, and P. Keen. 1989. Penetration of antibiotics into bovine neutrophils and their activity against Staphylococcus aureus. J. Antimicrob. Chemother. 24:709-718.

McDougall, S. 1998. Efficacy of two antibiotic treatments in curing clinical and subclinical mastitis in dairy cows. N.Z. Vet. J. 46:226-232.

Moroni, P., G. Pisoni, M. Antonini, R. Villa, P. Boettcher, and S. Carli. 2006. Short communication: Antimicrobial susceptibility of Staphylococcus aureus from subclinical bovine mastitis in Italy. J. Dairy Sci. 89:2973-2976.

Oliver, S. P., B. E. Gillespie, S. J. Headrick, H. Moorehead, P. Lunn, H. H. Dowlen, D. L. Johnson, K. C. Lamar, S. T. Chester, and W. M. Moseley. 2004. Efficacy of extended ceftiofur intramammary therapy for treatment of subclinical mastitis in lactating dairy cows. J. Dairy Sci. 87:2393-2400.

Owens, W. E., S. C. Nickerson, and C. H. Ray. 1999. Efficacy of parentally or intramammarily administered tilmicosin or ceftiofur against Staphylococcus aureus mastitis during lactation. J. Dairy Sci. 82:645-647.

Owens, W. E., C. H. Ray, J. L. Watts, and R. J. Yancey. 1997. Comparison of success of antibiotic therapy during lactation and results of antimicrobial susceptibility tests for bovine mastitis. J. Dairy Sci. 80:313-317.

Owens, W. E., J. L. Watts, R. L. Boddie, and S. C. Nickerson. 1988 Antibiotic treatment of mastitis: Comparison of intramammary and intramammary plus intramuscular therapies. J. Dairy Sci. 71:3143-3147.

Poutrel, B. 1978. Study of factors influencing the effectiveness of two treatments, penicillin-streptomycin and rifamycin, against experimentally induced staphylococcal mastitis in lactating cows. Ann. Rech. Vet. 9:471-487.

Rajala-Schultz, P. J., K. L. Smith, J. S. Hogan, and B. C. Love. 2004. Antimicrobial susceptibility of mastitis pathogens from first lactation and older cows. Vet. Microbiol. 102:33-42.

Rosenberg, J. B., B. Love, and D. L. Patterson. 2002. Bacterial cure and somatic cell count response of dairy cows with a positive California Mastitis Test at calving to therapy with cephapirin sodium. Vet. Therap. 3:381-386.

Sandgren, C. H., K. P. Waller, and U. Emanuelson. 2007. Therapeutic effects of systemic or intramammary antimicrobial treatment of bovine subclinical mastitis during lactation. Vet. J. doi:10.1016/j.tvjl.2006.12.005.
Sears, P. M., and K. K. McCarthy. 2003. Management and treatment of staphylococcal mastitis. Vet. Clin. North Am. Food Anim. Pract. 19:171-185.

Sérieys, F., and M. Gicquel-Bruneau. 2005. Within herd homogeneity of mastitis Staphylococcus aureus strains for the production of beta-lactamase and the resistance to benzylpenicillin. Page 813 in Proc. 4th IDF International Mastitis Conference, Maastricht. Wageningen Acad. Publ., Wageningen, the Netherlands.

Sérieys, F., Y. Raguet, L. Goby, H. Schmidt, and G. Friton. 2005. Comparative efficacy of local and systemic antibiotic treatment in lactating cows with clinical mastitis. J. Dairy Sci. 88:93-99.

Shephard, R. W., J. Malno, and D. U. Pfeiffer. 2000. A clinical trial to evaluate the effectiveness of antibiotic treatment of lactating cows with high somatic cell counts in their milk. Aust. Vet. J. 78:763-768.

Sobiraj, A., A. Kron, U. Schollmeyer, and K. Failing. 1997. Federal investigations on the distribution and in vitro resistance of udder pathogenic bacteria in the milk of cows with subclinical mastitis. Tierarztl. Prax. 25:108-115.

Sol, J., O. C. Sampimon, J. J. Snoep, and Y. H. Schukken. 1997. Factors associated with bacteriological cure during lactation after therapy for subclinical mastitis caused by Staphylococcus aureus. J. Dairy Sci. 80:2803-2808.

St. Rose, S. G., J. M. Swinkels, W. D. Kremer, C. L. Kruitwagen, and R. N. Zadoks. 2003. Effect of penethamate hydrochloride treatment on bacteriological cure, somatic cell count and milk production of cows and quarters with chronic subclinical Streptococcus uberis or Streptococcus dysgalactiae infection. J. Dairy Res. 70:387-394.

Swinkels, J. M., H. Hogeveen, and R. N. Zadoks. 2005a. A partial budget model to estimate economic benefits of lactational treatment of subclinical Staphylococcus aureus mastitis. J. Dairy Sci. 88:4273-4287.

Swinkels, J. M., R. G. Rooijendijk, R. N. Zadoks, and H. Hogeveen. 2005b. Use of partial budgeting to determine the economic benefits of antibiotic treatment of chronic subclinical mastitis caused by Streptococcus uberis or Streptococcus dysgalactiae. J. Dairy Res. 72:75-85.

Ziv, G. 1980. Drug selection and use in mastitis: Systemic versus local drug therapy. J. Am. Vet. Med. Assoc. 176:1109-1115.

Ziv, G., and M. Storper. 1985. Intramuscular treatment of subclinical staphylococcal mastitis in lactating cows with penicillin G, methicillin and their esters. J. Vet. Pharmacol. Therap. 8:276-283. 